\title{
Recycling of Secondary Aluminium Production Waste in Processing of Mullite Based Refractory Ceramics
}

\author{
D. Kirsever*, N. K. Karabulut, N. Toplan, H. O. Toplan \\ Sakarya University, Metallurgy and Materials Engineering, 54187 Sakarya, Turkey
}

\begin{abstract}
This work describes the studies to reuse secondary aluminium production waste (SAPW) derived from aluminium casting processes in the fabrication of mullite-based refractory ceramics. SAPW was characterized by using particle size analysis, X-ray diffraction (XRD), scanning electron microscopy (SEM) and X-ray fluorescence (XRF). Secondary aluminium production waste (SAPW), quartz and Grolleg kaolin were mixed stoichiometrically, according to chemical formula of mullite $\left(3 \mathrm{Al}_{2} \mathrm{O}_{3} \cdot 2 \mathrm{SiO}_{2}\right)$ by ball milling. Cylindrical samples were consolidated by uniaxial dry pressing and sintered at different temperatures (up to $1350{ }^{\circ} \mathrm{C}$ ). The phase and microstructural evolution, water absorption, bulk density, mechanical properties of sintered samples were investigated and refractory ceramics based on mullite were obtained.
\end{abstract}

DOI: 10.12693/APhysPolA.127.1035

PACS: 81.05.Je

\section{Introduction}

In recent years, secondary aluminium production wastes (SAPW) produced by aluminium casting processes are the alternative raw material in the manufacturing of mullite-based refractory ceramics. Predictable high alumina contents of SAPW makes them very attractive for recycling processes, such as the recovery of aluminium-based compounds [1]. Aluminosilicate-based ceramics such as mullite $\left(3 \mathrm{Al}_{2} \mathrm{O}_{3} \cdot 2 \mathrm{SiO}_{2}\right)$ have attracted much attention as a high-temperature structural ceramic, due to their good physical properties, such as low dielectric constant, low thermal expansion, high melting point, high resistance to creep, high temperature mechanical stability and resistance to chemical corrosion $[2,3]$. The preparation of mullite powders has been extensively studied in the literature. In particular, the reaction series of kaolinite or metakaolinite forms mullite [4]. The objective of this work was to study the influence of SAPW on mullite formation by means of X-ray diffraction (XRD), the mullite crystal morphology was investigated using scanning electron microscope (SEM). Also, the effects of the addition of SAPW on the bulk density, apparent porosity and microstructure of mullite ceramics were studied in detail.

\section{Experimental}

The chemical composition of raw materials are given in Table. 17 wt.\% $\mathrm{SiO}_{2}, 9$ wt.\% Grolleg kaolin and 74 wt.\% SAPW were used as starting materials for mullite formation. The composition of mullite was ball milled in water with $3 \mathrm{~mm} \mathrm{Al}_{2} \mathrm{O}_{3}$ balls in a polyethylene bottle for 2 hours and then filtered from salty water. The composition was dried at $100{ }^{\circ} \mathrm{C}$ for 24 hours. The samples were

\footnotetext{
* corresponding author; e-mail: dkirsever@sakarya.edu.tr
}

pressed at $90 \mathrm{MPa}$ (25 mm diameter) and then sintered in air at $1200,1250,1300,1350,1400,1450{ }^{\circ} \mathrm{C}$ for 1,3 and 5 hours with $10{ }^{\circ} \mathrm{C} / \mathrm{min}$ heating rate. The morphology of samples was observed by using Joel 6060 LV scanning electron microscope (SEM). The crystalline phases were analysed by X-ray diffraction analysis (XRD) using Rigaku Ultima X-ray diffractometer with $\mathrm{Cu} \mathrm{K}_{\alpha}$ radiation. After sintering, bulk density of samples were characterized by the Archimedes principle. Also, apparent porosity $(\%)$ and mullite formation $(\% C)$ were calculated using Eq. 1 and Eq. 2 respectively.

Apparent porosity $(\%)=[(w-d) /(w-s)] \times 100$. (1) Where $d$ is the dry weight, $w$ is the wet weight (weight after boiling in water and then removing surface water with a wet cloth), $s$ is the suspended weight.

$$
\% C=\left[B_{0} I_{x}\right] /\left[B_{x} I_{0}\right] \times 100 .
$$

Where $I_{0}$ is the integral intensity of the diffraction peak for the reference mullite powders, $B_{0}$ is the background of the diffraction peak for the non-activated mixture and $I_{x}$ and $B_{x}$ are the equivalent values for the mullite crystallization (the reference mullite is Nabaltec mullite and the JCPDS card number is 01-079-1454). The integrated intensity of the (121) XRD reflection ( $2 \theta$ from 40.5 to $41.5)$ was measured to determine to content of the mullite phase [5].

The chemical composition of raw material.

TABLE

\begin{tabular}{l|c|c|c|c|c|c|c|c}
\hline \hline & $\mathrm{Al}_{2} \mathrm{O}_{3}$ & $\mathrm{Fe}_{2} \mathrm{O}_{3}$ & $\mathrm{CaO}$ & $\mathrm{K}_{2} \mathrm{O}$ & $\mathrm{Na}_{2} \mathrm{O}$ & $\mathrm{MgO}$ & $\mathrm{Cl}$ & $\mathrm{TiO}_{2}$ \\
\hline $\mathrm{SAPW}$ & 69.87 & 3.05 & 1.78 & 4.586 & 6.24 & 2.74 & 9.454 & 0.444 \\
Kaolin & 33.83 & 0.55 & 0.15 & 0.13 & 0.01 & 0.05 & - & 0.45 \\
Quartz & 0.28 & 0.05 & 0.10 & - & 0.17 & 0.06 & - & 0.05 \\
\hline & $\mathrm{BaO}$ & $\mathrm{SiO}_{2}$ & $\mathrm{ZnO}$ & $\mathrm{CuO}$ & $\mathrm{MnO}$ & $\mathrm{Cr}_{2} \mathrm{O}_{3}$ & L.O.I $^{a}$ & \\
\hline SAPW & 0.356 & 0.852 & 0.0324 & 0.132 & 0.0937 & 0.0923 & 0.27 & \\
Kaolin & - & 52.12 & - & - & - & - & 12.45 & \\
Quartz & - & 99.1 & - & - & - & - & 0.19 &
\end{tabular}

${ }^{a}$ Loss on ignition 


\section{Results and discussion}

Figure 1 shows the XRD patterns of sintered samples as heated at $1200,1250,1300,1350,1400,1450{ }^{\circ} \mathrm{C}$ for 1 hour. When the samples were sintered at $1200{ }^{\circ} \mathrm{C}$ for $1 \mathrm{~h}$, the quartz and alumina have been noted to be the major phases. The mullite phase appeared as the sample was sintered at $1300{ }^{\circ} \mathrm{C}$ for $1 \mathrm{~h}$. When sintering temperatures elevated to between 1300 and $1450{ }^{\circ} \mathrm{C}$, the intensity increased and the much sharper X-ray reflections of mullite were observed. It is found that quartz and alumina reacted completely and had mainly converted to mullite phase at $1450{ }^{\circ} \mathrm{C}$. The mullite formation increased with the heating temperature increasing from 1200 to $1450{ }^{\circ} \mathrm{C}$. The bulk density and apparent porosity of samples are given in Fig 2. It is clear that the bulk density of samples increased with sintering temperature. The bulk density and apparent porosity values of sample after sintering at $1450{ }^{\circ} \mathrm{C}$ for $1 \mathrm{~h}$ were $2.15 \mathrm{~g} \mathrm{~cm}^{-3}$ and $12.1 \%$, respectively. Open porosity decreased with the increase of density and the minimal porosity was obtained at $1450{ }^{\circ} \mathrm{C}$. There was a $20 \%$ increase in density when the temperature increased from 1400 to $1450{ }^{\circ} \mathrm{C}$. This is related to the fact that higher sintering temperatures lead to the formation of a vitreous phase which enhances mass transfer through viscous flow [6].

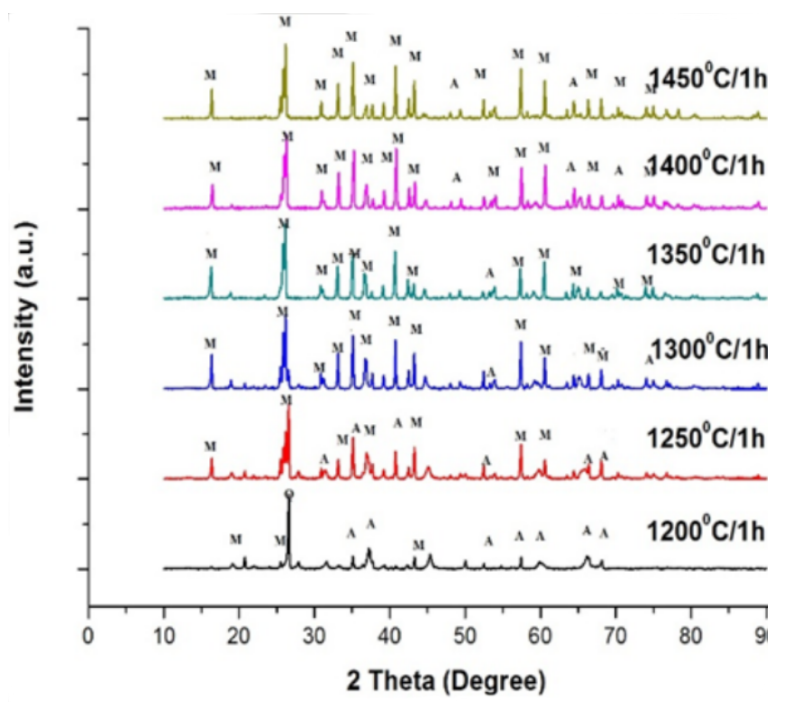

Fig. 1. X-ray diffraction analysis of samples sintered at $1200-1450{ }^{\circ} \mathrm{C}$ for 1 hour. (M: Mullite, $\mathrm{A}: \mathrm{Al}_{2} \mathrm{O}_{3}$, Q: $\left.\mathrm{SiO}_{2}\right)$.

Figure 3 shows the SEM micrographs of the samples sintered at $1200,1250,1300,1350,1400,1450{ }^{\circ} \mathrm{C}$ for 1 hour. The pores (black areas) were mainly located between the interface of alumina and mullite grains. A network of mullite crystals embedded in abundant glassy phase (dark gray areas) and agglomerates of alumina crystals surrounded by a glass phase are visible. The pore size and distribution significantly decreased with increasing sintering temperature. Needle-like mullite grains can be seen at low sintering temperatures, but the densifica-
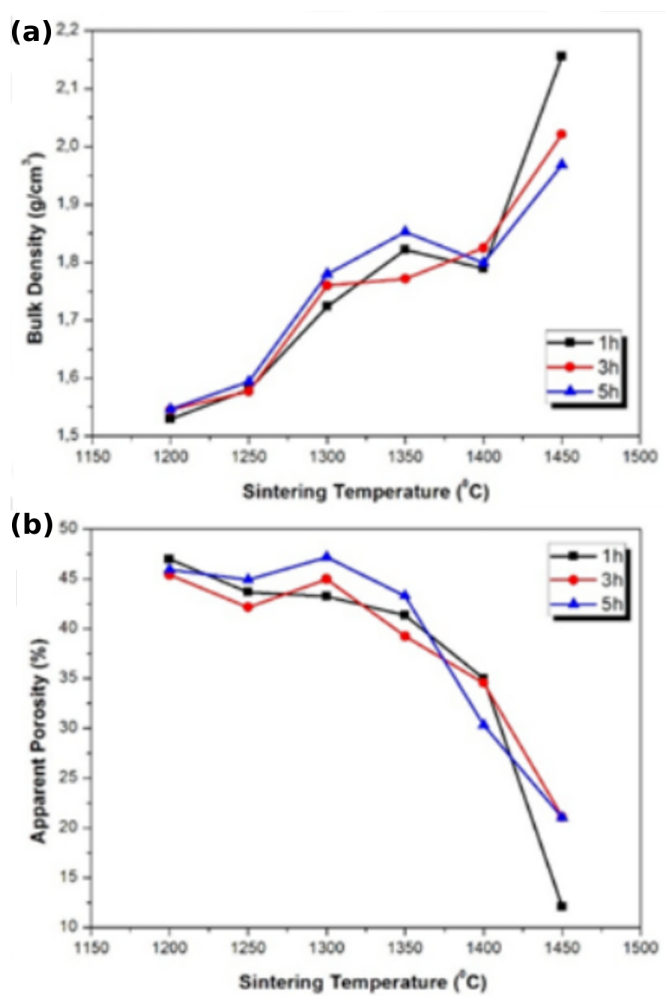

Fig. 2. Bulk density (a), and apparent porosity (b), of samples sintered at $1200-1450{ }^{\circ} \mathrm{C}$ for 1,3 and 5 hours.
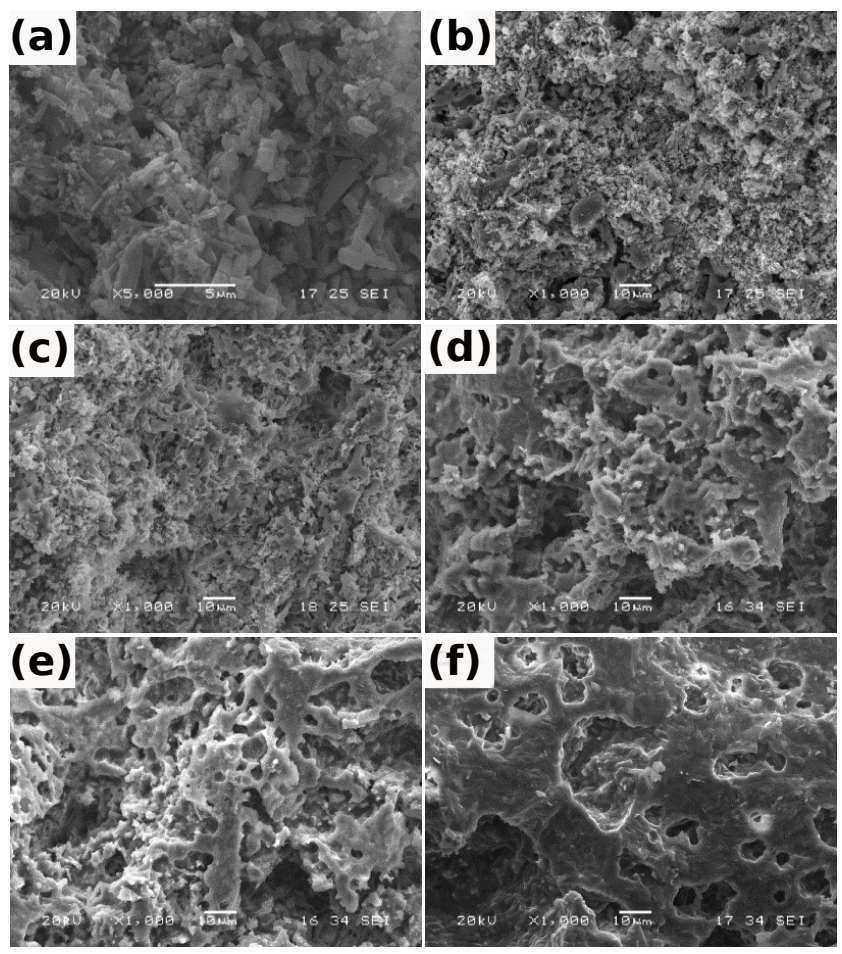

Fig. 3. SEM micrographs of all samples sintered at (a) $1200{ }^{\circ} \mathrm{C}$, (b) $1250{ }^{\circ} \mathrm{C}$, (c) $1300{ }^{\circ} \mathrm{C}$, (d) $1350{ }^{\circ} \mathrm{C}$, (e) $1400{ }^{\circ} \mathrm{C}$, (f) $1450{ }^{\circ} \mathrm{C}$ for $1 \mathrm{~h}$. 


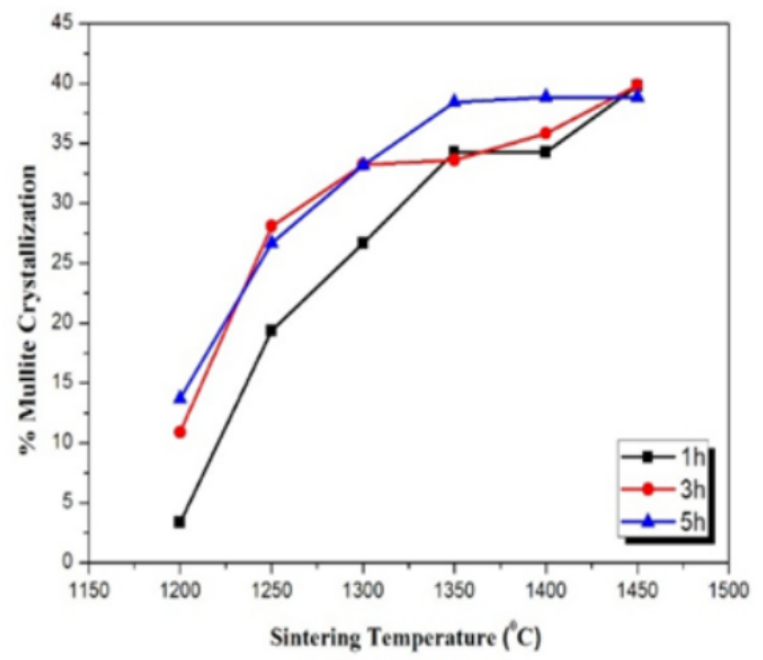

Fig. 4. Mullite crystallization of all samples sintered at $1200-1450{ }^{\circ} \mathrm{C}$ for 1,3 and 5 hours.

tion increased at high temperatures. The mullite crystallization of samples sintered at 1200, 1250, 1300, 1350, $1400,1450{ }^{\circ} \mathrm{C}$ for 1,3 and 5 hours is given in Fig. 4 . The majority of researchers studying the mullite crystallization use only the change of XRD intensities as an extent of mullite transformation. As shown in Fig. 4, the mullite crystallization increased with sintering temperature and time. The mullite crystallization of $40 \%$ was observed for samples sintered at $1450{ }^{\circ} \mathrm{C}$ for 1 and 3 hours.

\section{Conclusion}

This research has shown that secondary aluminium production waste products may be used as raw material for production of mullite based ceramics. The highest densification was obtained at high sintering temperatures and high sintering times. Open porosity has decreased with the increase of density and the minimum porosity was obtained at $1450{ }^{\circ} \mathrm{C}$. The mullite crystallization increased with sintering temperature and time.

\section{References}

[1] I.D. Kashcheev, T.V. Bayandina, A.I. Usherov, V.I. Shishkin, I.V. Shishkin, Refract. Ind. Ceram. 49, 167 (2008).

[2] C. Aksel, Ceram. Int. 29, 183 (2003).

[3] E. Ozel, S. Kurama, Ceram. Int. 36, 1033 (2010).

[4] J. Pascual, J. Zapatero, M.C.J. de Haro, A.J.R. del Valle, J.L. Pérez-Rodríguez, P.J. SánchezSoto, J. Am. Ceram. Soc. 83, 2677 (2000).

[5] E. Elmas, K. Yildiz, N. Toplan, H.Ö. Toplan, Mater. Tehnol. 47, 413 (2013).

[6] F.A.C. Oliveira, V. Livramento, F. Delmas, J. Mater. Process. Technol. 196, 101 (2008). 